Vol. 39(1), pp. 59-71, June 2020

ISSN 1821-536X (print)

ISSN 2619-8789 (electronic)
Tanzania Journal of Engineering and Technology

Copyright (c) 2020 College of Engineering and

Technology, University of Dar es Salaam

Full Length Research Paper

\title{
Estimating Flood Magnitudes of Ungauged Urban Msimbazi River Catchment in Dar es Salaam, Tanzania
}

\author{
Patrick Valimba ${ }^{1,2}$ and Gil Mahé ${ }^{3}$ \\ ${ }^{1}$ Department of Water Resources Engineering, University of Dar es Salaam, Tanzania. \\ ${ }^{2}$ Foundation for Water Research, P.O. Box 10240, Dar es Salaam, Tanzania. \\ ${ }^{3}$ IRD, Hydro-Sciences Montpellier, Université de Montpellier, Case courier MSE, Place \\ Eugène Bataillon, F-34095 Montpellier Cedex 5, France \\ E-mail corresponding author:pvalimba@yahoo.com, pvalimba@hotmail.com
}

\begin{abstract}
More often daily climate data have been used in hydrological models to estimate flood flows in small data scarce urban and rural catchments where flow peaking and recession are quick within short periods of few hours. This study assesses magnitudes of error of using daily climate data to simulate flood flow hydrographs of a small urban river catchment, Msimbazi River. Spot discharge measurements were available for Apr-May 2014 and MarMay 2015 periods.10-minutes climate records were available at one station, daily temperatures at two stations while daily rainfall records at several stations within the catchment. Visual analysis characterise rainfall events during the 2011, 2014 and 2015 floods, Thiessen-polygon was used for catchment rainfall, Hargreave-Samani model for catchment potential evapotranspiration and flow hydrographs were estimated by calibrated HBV model. Length weighted channel slope was estimated from segment slopes established from available topographical maps and used in estimating time of concentration for the catchment using Kirpich method. Results indicated that simulated flood hydrographs using 10-minutes climate inputs produced higher flood peaks for both December 2011 (peak: $471.6 \mathrm{~m}^{3} / \mathrm{s}$ ) and April 2014 (peak: $393.5 \mathrm{~m}^{3} / \mathrm{s}$ ) and expected hydrograph recession behaviour reproducing the Kirpich estimate of time of concentration of 7 hours. Simulated flood peaks using daily climate inputs were $252.3 \mathrm{~m}^{3} / \mathrm{s}$ for December 2011 and $205 \mathrm{~m}^{3} / \mathrm{s}$ for the April 2014 event being 53\% and 52\% of those simulated from 10-minutes climate inputs. Despite usefulness of 10-minute climate data, these data are required at more stations within the catchment for reliable simulation of fast receding urban floods and therefore more automatic weather stations are needed in Dar es Salaam.
\end{abstract}

Key words: Flood hydrographs, Hargreave-Samani model, hydrological models, Kirpich method, Thiessen-polygon. flood hydrographs, ungaged urban river.

\section{INTRODUCTION}

Riverine floods have been a constant threat to people inhabiting low-lying areas and floodplains, which have either been associated with overflows of water into floodplains and/or exceptionally high instream river stages. Tanzania has large number of floodplains, which are normally and annually inundated with flood water, and pass exceptionally extreme and rare high flood water in extremely wet years receiving abundant rains. Consequently, several regions of Tanzania have 
experienced floods of different magnitudes in the past, events which were rarely documented (EM-DAT, 2008).

The threat of floods is greatest in urban floodplains including Msimbazi floodplain in Dar es Salaam with increasing impacts in Dar es Salaam in the last 10 years. Several floods of different severity level have occurred in December 2011, April 2014, May 2015, April 2016, March 2017, and April 2018 affecting people and properties in various areas. Although floods have been annual events during the Masika (long rains) season in March-May period in the Msimbazi floodplain, the recent floods have hit many areas in the city some far from the Msimbazi floodplain and some events occurring unusually during the Vuli (short rains) season in October-December period. However, the most frequently affected areas are located in Ilala District of Dar es Salaam (Figure 1) and specifically in the Msimbazi floodplain (Figure 2) into which River Msimbazi is joined by its large tributaries, Rivers Luhanga, Ubungo and Sinza before discharging into the Indian Ocean at Selander Bridge.

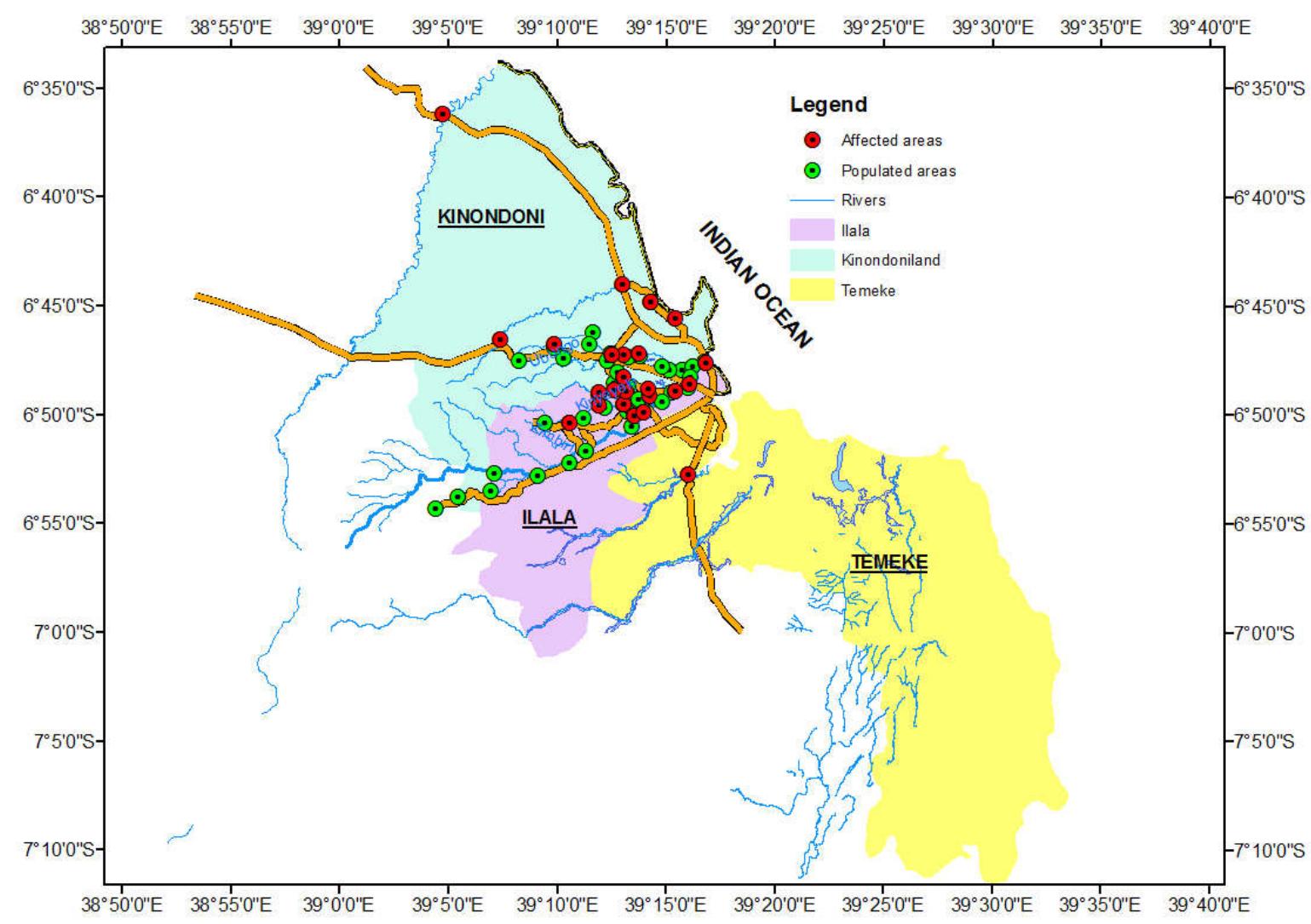

Figure 1: Areas affected by recent floods in Dar es Salaam.

Although floods in Dar es Salaam have occurred in 6 of the last 8 years, they were caused by heavy rains of different patterns occurring as single or multiple events within 24 hours lasting between 1 and 3 days. Consequently, there are similarities and differences between the recent floods in terms of volumetric flows, area extent and duration. The 2011, 2017 and 2018 floods extended for the entire lower Msimbazi flood plain (VingungutiJangwani-Selander Bridge) while the 2014, 2015 and 2016 extended for the Jangwani-Selander Bridge portion of the floodplain. Owing to such variability in the flood characteristics, these floods had different levels of impacts in the natural, social and economic systems of Dar es 
Salaam including impacts of inundation on settlements, loss of lives, damages to river cross sections, damages to road infrastructure, damages to buildings and paralysis of transport services.

Management of Dar es Salaam floods is hindered by the lack of hydrographic monitoring network as a few gauges had historically been installed and operated predominantly before the independence in 1961. However, most of them were closed, damaged and/or records missing. As a result, it is difficult to provide quantification of how large volumes of water have been passing during the recent floods although the floods peaks lasted for some hours before levels receded to low stages. Fortunately, there has been continuous monitoring of rainfall and climate variables at several stations in and around the city with varying observation intervals from minutes to 24 hours, which can be used to estimate quantities of water passed during the recent flood events.

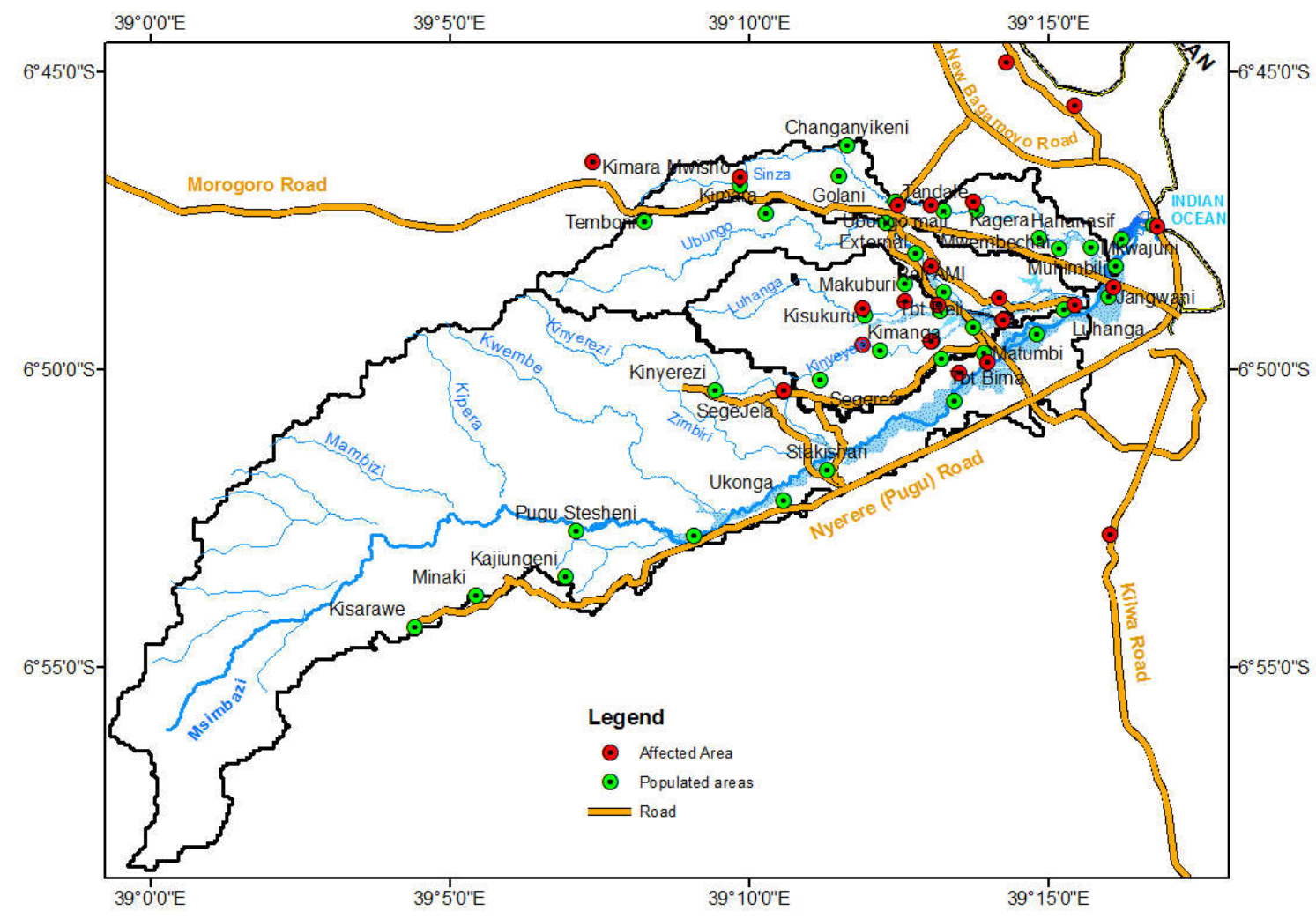

Figure 2: Sub-catchments of Msimbazi catchment showing flood affected areas.

Unavailability of continuous flow records at old gauging stations in Msimbazi catchment classifies it as hydrologically ungauged catchment. However, these catchments may have partial or fully available climate records at various locations within and around them. In such cases where data is scarce or unavailable, the hydrologists have developed models and techniques which do not require the availability of long time series of meteorological and hydrological observations (Loukas and Vasiliades, 2014; Blöschl et al., 2013; Botero and Francés, 2010; Nag and Biswal, 2019; Post, 2004). Depending on whether flow hydrographs, statistics or quantiles are the required outputs, several methods can be used including rainfall-runoff modelling using global parameters transfer, quantile estimation from empirical methods and time series summaries from flow duration curves (FDC) regional equation (Swain and Patra, 2017; Valimba, 2016; Loukas 
and Vasiliades, 2014). They fall into either statistical, hydrological modelling or stochastic modelling methods (Loukas and Vasiliades, 2014) and more often employed simultaneously.

Unavailability of continuous flow records in Msimbazi catchment have hindered application of rainfall-runoff or routing models in the generation of long discharge records for studying behaviour of flood hydrographs and flooding in the catchment. Anchor Environmental Consultants (2016) have estimated flood quantiles in Msimbazi catchment using statistical methods. No attempt has yet been made to use hydrological and stochastic models in this catchment as have been applied elsewhere where model parameters have been transferred from gauged catchments (Gandry et al., 2013; Valimba, 2016; Valimba, 2019). This approach would provide the entire flood hydrographs as used in Mazvimavi (2003), Deckers (2006), Bárdossy (2007), Perera (2009) and Fionda (2011). They include full transfer of optimum model parameters to target catchment from a nearby catchment (spatial proximity), a similar catchment (spatial similarity or physical reasoning) or used regression-based regionalisation of model parameters. These approaches have their own strengths and weaknesses (Bárdossy, 2007; Bastola et al., 2008).

Lack of stream-flow records in this small Msimbazi catchment result in the catchment being treated as hydrologically ungauged where empirical methods have been used in estimating flood quantiles (Anchor Environmental Consultants, 2016). Despite successes in establishing flood quantiles, it was not possible to study behaviour of the recent floods including peaking time and recession behaviour, which are important in relation to managing impacts of flooding. Availability of few spot discharge measurements at various locations along
River Msimbazi and daily/sub-daily (10minutes) climate data provides opportunities for the use of hydrological modelling to simulate flood flow hydrographs during the recent floods. Moreover, flood hydrograph behaviour (flow magnitudes and recessions) of small fast draining urban catchments have often been underestimated when daily climates have been used. Therefore, the objective of this study was to assess suitability of observation time intervals in the estimation of flood magnitudes and recession of fast draining urban River Msimbazi in Dar es Salaam.

\section{METHODS AND MATERIALS}

\section{The Study Area}

The surface water resources within the Msimbazi catchment (268.17 $\left.\mathrm{km}^{2}\right)$ comprise the riverine and palustrine wetlands systems organised within smaller sub-catchments of major tributaries draining into River Msimbazi. The subcatchments are related to drainage locations of major tributaries with respect to the seasonally inundated Msimbazi floodplain. Consequently, all tributaries draining into River Msimbazi upstream of the floodplain (Kinyerezi, Zimbiri, Kwembe, Kipera, Mambizi, etc) are within the main Msimbazi sub-catchment while tributaries draining directly into River Msimbazi within the main floodplain (Sinza, Ubungo, Luhanga) form separate sub-catchments (Figure 2). This division considers the overflow of the three rivers which, during extreme flooding, contribute directly to floodplain flow before reaching their confluences with River Msimbazi. These sub-catchments are largest main Msimbazi sub-catchment (68.4\%), Ubungo sub-catchment (11.4\%), Sinza subcatchment $(8.8 \%)$ and Luhanga subcatchment $(11.1 \%)$. The permanently inundated estuary at Msimbazi Bay is $0.3 \%$ of the catchment. Consequently, much of water draining through the 
floodplain comes from the main Msimbazi sub-catchment, whose largest area lies upstream of the River Kinyerezi confluence (Figure 2).

\section{River Discharge Records}

River Msimbazi had historically been gauged at Stakishari (1J4), whose record is missing. Several other rivers in catchments around Msimbazi sub-catchment in Dar es Salaam had historically been gauged particularly before independence including Sinza at Ubungo (1J2), Mlalakuwa at Colito Barracks (now Lugalo Barracks, 1J3), Mbezi at Bigwa downstream (1J7),
Kizinga at Mbagala/Buza (1J8) and Mzinga at Majimatitu (1J6) and at Kichemichemi (1J9). However, most of them were closed, damaged or missing records hindering estimation of Msimbazi discharge. Consequently, spot discharge measurements were carried out at 5 strategic locations (Figure 3) along River Msimbazi between Stakishari-Segerea Road Bridge and Tabata Matumbi upstream of Railway Bridge (Table 1). The first two sites (MS1 and MS2) are located upstream of overflow sections while other sites are located in the potential overflow locations.

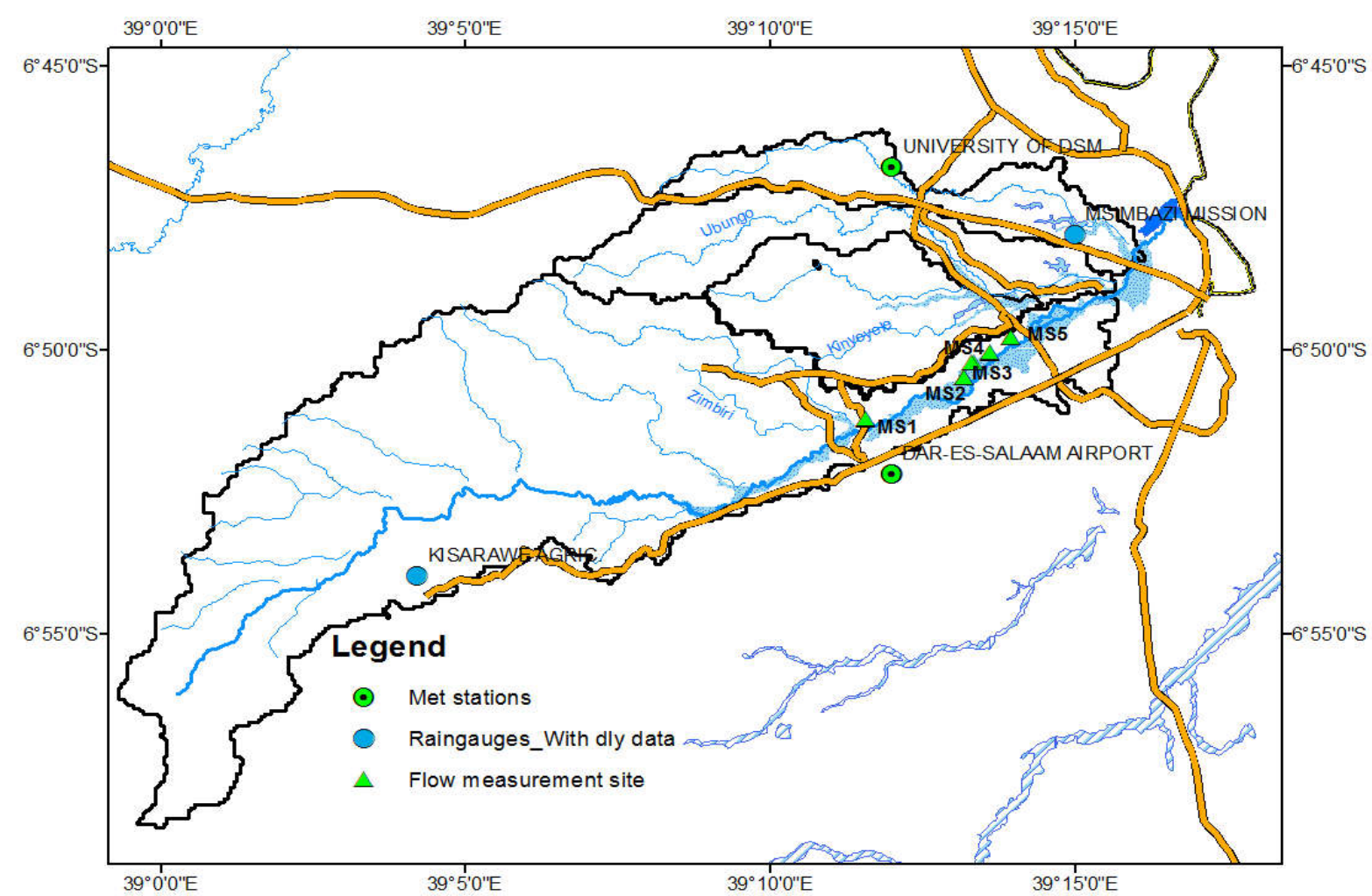

Figure 3: Flow measurements sites, rainfall and climate stations in and around Msimbazi catchment with daily and/or sub-daily data.

During all recent extreme flooding events, water remained in-stream at MS1 while slightly overflew the Vingunguti (MS2) road bridge. This MS1 site has stable cross section of clayey banks and bed with an estimated bankful discharge $603 \mathrm{~m}^{3} / \mathrm{s}$ at $3.59 \mathrm{~m}$ stage of the right bank. Owing to large number of flow measurements and its location with respect to measurements of flows, MS1 site was selected for quantification of flood discharges. It has 4 spot discharge measurements in the AprMay 2014 period, 5 measurements in the Mar-May 2015 period and 2 data points in May 2018. 
Table 1: Spot measurement sites along river Msimbazi.

\begin{tabular}{|c|c|c|c|c|c|}
\hline Code & Location & $\mathrm{N}$ & $\mathrm{E}$ & $\begin{array}{l}\text { Data } \\
\text { points }\end{array}$ & Dates \\
\hline MS1 & $\begin{array}{l}\text { Stakishari-Segerea washed } \\
\text { away Road Bridge }\end{array}$ & 9242173.92 & 521429.3 & 11 & $\begin{array}{l}\text { 11 Apr } 2014- \\
17 \text { May } 2018\end{array}$ \\
\hline MS2 & $\begin{array}{ll}\text { Downstream } & \text { Vingunguti } \\
\text { Road Bridge } & \end{array}$ & 9243584.58 & 524472.1 & 5 & $\begin{array}{l}1 \text { May } 2014- \\
18 \text { May } 2015\end{array}$ \\
\hline MS3 & Tabata-Bima & 9244996.46 & 525413.30 & 4 & $\begin{array}{l}12 \text { May } 2015- \\
21 \text { May } 2015\end{array}$ \\
\hline MS4 & Tabata-Shule & 9244554.53 & 524971.12 & 4 & $\begin{array}{l}\text { 12 May } 2015- \\
21 \text { May } 2015\end{array}$ \\
\hline MS5 & $\begin{array}{l}\text { Tabata-Matumbi upstream } \\
\text { railway bridge }\end{array}$ & 9244813.91 & 525896.3 & 4 & $\begin{array}{l}\text { 12 May } 2015- \\
21 \text { May } 2015\end{array}$ \\
\hline
\end{tabular}

\section{Rainfall and Climate Records}

There are two meteorological stations in Dar es Salaam, the Julius Nyerere International Airport (JNIA) and University of Dar es Salaam (UDSM). Several rain gauges existed and few are still existing within and around the catchment with records in various periods of the 1898-2018 period. Only three stations UDSM, JNIA and Kisarawe Agriculture have data available in the recent floods period (December 2011 May 2018). Daily rainfall records were available at all three stations while daily minimum and maximum temperature records were available at the two met stations (UDSM, JNIA). 10-minutes rainfall/climate records were available at UDSM for the 15 Dec 2011 - 25 Mar 2015 period and sub-daily rainfall/climate data were not readily availed for the study. At every 10 minutes interval, minimum and maximum temperatures were taken as lowest and highest temperatures between any two successive intervals. Hourly minimum and maximum temperatures were taken as lowest and highest of the six temperatures in an hour while hourly rainfall series were accumulations of rainfall amounts received in particular hours.

\section{Catchment Topography and Slopes}

The study used topographical maps of Dar es Salaam at 1:50,000 scale covering the entire catchment with a contour interval of $20 \mathrm{~m}$. From topographical maps, lengths of River Msimbazi were measured between consecutive contour lines and slopes were calculated for each river segment between two contour lines (Table 1). Final catchment slope $(S)$ of $0.005165 \mathrm{~m} / \mathrm{m}$ was computed as a weighted average slope calculated as (UDFCD, 2018).

$$
S=\left[\frac{L_{1} S_{1}^{0.24}+L_{2} S_{2}^{0.24}+L_{3} S_{3}^{0.24}+\ldots . .+L_{n} S_{n}^{0.24}}{L_{1}+L_{2}+L_{3}+\ldots \ldots+L_{n}}\right]^{4.17}
$$

where $S_{i}$ are segment slopes and $L_{i}$ segment lengths.

\section{Catchment Response Time}

Observation of recent floods in Dar es Salaam revealed short living flood peaks, which recedes quickly to normal flows. Flow peaks are a result of runoff 
contributions from all parts of catchment areas and time taken to contribute to outflows (time of concentration) has been estimated from minutes to a few $(<4)$ hours in several catchments of Dar es Salaam ranging in size from $1.5 \mathrm{~km}^{2}$ to 20 $\mathrm{km}^{2}$ (Msangi, 2017). To understand adequacy of climate records in simulating rapidly receding flood peaks of River
Msimbazi, time of concentration $\left(t_{c}\right)$ in minutes was estimated using a Kirpich (1940) method given by equation (2).

$t_{c}=0.0195 \frac{L^{0.77}}{S^{0.385}}$

where $L$ is the maximum distance travelled by water $(\mathrm{m})$ and $S$ is the slope along the water path $(\mathrm{m} / \mathrm{m})$.

Table 1: Segment slopes of River Msimbazi along the main river course.

\begin{tabular}{|c|c|c|c|c|}
\hline & \multicolumn{2}{|c|}{ Distance (m) } & \multicolumn{2}{c|}{ Slope (m/m) } \\
\cline { 2 - 5 } Alt (m) & Cumulative & Segment & Segment & LS $^{\mathbf{0 . 2 4}}$ \\
\hline 232 & 0 & & & \\
\hline 220 & 173.9 & 173.9 & 0.069005 & 0.002777 \\
\hline 200 & 1271 & 1097.1 & 0.018230 & 0.012730 \\
\hline 180 & 3163.6 & 1892.6 & 0.010567 & 0.019266 \\
\hline 160 & 5882.2 & 2718.6 & 0.007357 & 0.025371 \\
\hline 140 & 9032.1 & 3149.9 & 0.006349 & 0.028374 \\
\hline 120 & 12536.4 & 3504.3 & 0.005707 & 0.030769 \\
\hline 100 & 17291.1 & 4754.7 & 0.004206 & 0.038800 \\
\hline 80 & 22374.7 & 5083.6 & 0.003934 & 0.040824 \\
\hline 60 & 27660.8 & 5286.1 & 0.003784 & 0.042056 \\
\hline 40 & 32492.8 & 4832 & 0.004139 & 0.039279 \\
\hline 39.6 & 32962.4 & 469.6 & 0.000852 & 0.002612 \\
\hline \multicolumn{5}{|c}{$\mathbf{S}=\mathbf{0 . 0 0 5 1 6 5} \mathbf{~ m} / \mathbf{m}$} \\
\hline
\end{tabular}

\section{Establishment of Catchment Climate Series}

A Thiessen polygon method gave weights of 0.746 and 0.254 to Kisarawe Agriculture and JNIA stations, which were used in determining catchment daily rainfall series between $1^{\text {st }}$ September 2011 and $30^{\text {th }}$ June 2017 as sum of products of these weights to respective daily rainfall amounts at the two stations. Daily potential evapotranspiration (PET) series was computed from minimum, maximum and mean daily temperatures at JNIA using Hargreave-Samani (1985) method given by equation (3).

$$
P E T=0.0023 R_{a}\left[T_{m}+17.8\right] \sqrt{\left(T_{\text {max }}-T_{\text {min }}\right)} \quad[\mathrm{mm} / \mathrm{d}]
$$

where $R_{a}$ is extraterrestrial radiation $(\mathrm{MJ} / \mathrm{m} / \mathrm{d}), \quad T_{m}, \quad T_{\min }$ and $T_{\max }$ are daily/hourly/10-minutes mean, minimum and maximum air temperatures $\left({ }^{\circ} \mathrm{C}\right)$. The extraterrestrial radiation is estimated from equation (4).

$R_{a}=15.392 d_{r}\left(\omega_{s} \sin \varphi \sin \delta+\cos \varphi \cos \delta \sin \omega_{s}\right)$ 
where $d_{r}$ is the relative distance between the earth and the sun given by $d_{r}=1+$ $0.033 \cos \left(\frac{2 \pi J}{365}\right)$, $\mathrm{J}$ is the Julian day ( 1 for $1^{\text {st }}$ January, 365 or 366 for $31^{\text {st }}$ December), $\varphi$ is latitude (radians: $\left.\frac{\pi L a t\left(^{\circ}\right)}{180}\right)$ at JNIA ($\left.6.87^{\circ}\right), \delta$ is declination of the sun (radians) given by $\delta=0.4093 \sin \left(2 \pi \frac{J+284}{365}\right)$ and $\omega_{s}$ is the sunset hour angle given by $\omega_{s}=$ $\arccos (-\tan \varphi \tan \delta)$.

Ten-minutes catchment series (rainfall, evapotranspiration) were established from catchment daily series. Using UDSM 10 minutes data, 10 minutes rainfall and evapotranspiration fractions were computed as the ratio between 10 minutes data to daily data between $15^{\text {th }}$ December 2011 and $25^{\text {th }}$ March 2015. Field experience of spatial occurrences of the 2011, 2014 and 2015 events within the 24 hours period indicated comparable onsets and distributions of the rains between UDSM and JNIA stations. This fact supported the presumption of similar time distribution of sub-daily (10-minutes, hourly) rainfall within the study catchment. The computed fractions were therefore applied to disaggregate daily catchment series into 10 minutes data. Hourly series were established by aggregation of 10 minute series.

\section{Hydrological Modelling}

Whilst several rainfall-runoff models may be used, HBV model was selected due to being free, availability of data necessary for deriving its inputs (rainfall, temperature, evaporation) and use experience. HBV model was calibrated for

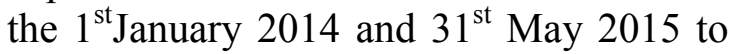
take advantage of available spot discharge measurements. The model was calibrated separately using daily, hourly and 10minutes rainfall, average temperature and PET series. An automatic optimisation routine (GAP optimisation) embedded in the HBV Light software was used to automatically establish optimum values of model parameters. Owing to a small number of spot discharge measurements, model fitting efficacy was assessed by comparing the nine (9) spot discharges against model estimates where deviations were computed and used to classify magnitudes of deviations as provided in the draft EWA guidelines (URT, 2017) as small $(<10 \%)$, moderate $(10-20 \%)$, slightly large (20-30\%) and high (>30\%).

\section{RESULTS AND DISCUSSION}

\section{Flood Hydrographs}

\section{Hydrographs from daily climate inputs}

An HBV model calibrated with daily climate closely reproduced well spot discharge measurements (Figure 4) capturing both measured low and high flows at MS1. Comparison of estimated and observed indicates predominant underestimation of discharges by the model (Table 2) with deviations being small $(<10 \%)$, slightly large $(20-30 \%)$ to large $(>20 \%)$. Moreover, the daily climates produced the peak daily discharge of $205 \mathrm{~m}^{3} / \mathrm{s}$ on 11 April during calibration period. Generated daily discharges for the $1^{\text {st }}$ December $2011-31^{\text {st }}$ June 2017 period using the calibrated daily model simulated the highest daily discharges of $252.3 \mathrm{~m}^{3} / \mathrm{s}$ on $21^{\text {st }}$ Dec 2011 , followed by $205.0 \mathrm{~m}^{3} / \mathrm{s}$ on $11^{\text {th }}$ Apr 2014, $202.8 \mathrm{~m}^{3} / \mathrm{s}\left(12^{\text {th }}\right.$ Apr $2014), 169.4 \mathrm{~m}^{3} / \mathrm{s}\left(6^{\text {th }}\right.$ May 2015$)$ and 65.6 $\mathrm{m}^{3} / \mathrm{s}\left(7^{\text {th }}\right.$ May 2015$)$.

\section{Hydrographs from 10-min. climate inputs}

Similarly, HBV model was calibrated with 10 -minutes series for $1^{\text {st }}$ January to $31^{\text {st }}$ May 2014 period. Simulated discharges almost reproduced the April and May 2014 spot measurements with very small $(\leq 3 \%)$ magnitude deviations (Table 2). Similar small deviation $(1.5 \%)$ between simulated and measured discharges was obtained for the $25^{\text {th }}$ March 2015 event and the 
calibrated model was considered suitable for simulation of flood hydrographs during the 2011 and 2014 flood events.

Simulated 10-minutes discharges using calibrated HBV model between 9:00 hours of $10^{\text {th }}$ April 2014 (before flood) through flooding days $\left(11^{\text {th }}\right.$ and $12^{\text {th }}$ April 2014) indicated 6 peaks, three with discharges exceeding $300 \mathrm{~m}^{3} / \mathrm{s}$ and another two exceeding $150 \mathrm{~m}^{3} / \mathrm{s}$ (Figure 5). These peaks exceed 124,81 and $149 \mathrm{~m}^{3} / \mathrm{s}$ being capacities of River Msimbazi at TabataBima (MS3), Tabata-Shule (MS4) and Tabata-Matumbi (MS5), respectively. The hydrograph indicates short-lived overflows occurred as early as on morning of $10^{\text {th }}$ April at Tabata Shule (localised overflow), repeated on the morning of $11^{\text {th }}$ April and became long-lived covering the entire Tabata Bima-Tabata Matumbi reach by evening of $11^{\text {th }}$ April 2014 (Figure 5). The $222 \mathrm{~m}^{3} / \mathrm{s}$ measured discharge at 17:4018:30 hours of $11^{\text {th }}$ April was part of this longer event of $11^{\text {th }}$ April 2014, which peaked at 19:40 hours with a discharge of $307 \mathrm{~m}^{3} / \mathrm{s}$. However, the longest overflow event is simulated between 10:00 hours and 19:00 hours of $12^{\text {th }}$ April with the highest discharge of $393.5 \mathrm{~m}^{3} / \mathrm{s}$ simulated at 10:40 hours.

Simulated 10 minute discharges on $20^{\text {th }}$ and $21^{\text {st }}$ December 2011 indicate two distinct high peaks of 289.8 and 471.6 $\mathrm{m}^{3} / \mathrm{s}$, respectively (Figure 6). In fact, the peaks are broad with discharges exceeding $150 \mathrm{~m}^{3} / \mathrm{s}$ lasting between 06:10 and 08:30 hours on $20^{\text {th }}$ December and 07:00 and 10:50 hours on $21^{\text {st }}$ December 2011. Whilst simulated highest daily (252.3 $\left.\mathrm{m}^{3} / \mathrm{s}\right)$ and 10 -minute $\left(289.8 \mathrm{~m}^{3} / \mathrm{s}\right)$ on $20^{\text {th }}$ December are not very different, the highest 10-minute discharge of $471.6 \mathrm{~m}^{3} / \mathrm{s}$ on $21^{\text {st }}$ December could not be simulated by daily inputs. However, this was the day of December 2011 floods which observed the most severe flooding to hit Msimbazi Valley in the recent decades (Manyangu 2011; Mujwahuzi, 2011). This further suggests inability of daily climate inputs in generating flow magnitudes of flash floods typically occurring in small urban catchments of Tanzania during flooding events.

A comparison of flood peaks simulated from 10-minute and daily climate inputs indicates significant underestimation of flood flows when daily series are used. The 10-minute simulated peaks of 307 and $393.5 \mathrm{~m}^{3} / \mathrm{s}$ on $11^{\text {th }}$ and $12^{\text {th }}$ April 2014 were significantly underestimated by simulations at daily time intervals as 205 and $201.8 \mathrm{~m}^{3} / \mathrm{s}$, respectively. This has significant implications in the design of hydraulic structures to protect against and pass the flood flows.

\section{Rainfall Patterns During Flooding}

The April 2014 events were isolated multiple events lasted for 16-17 hours. Six (6) events of $11^{\text {th }}$ April occurred between 06:40 and 22:40 hours (16 hours) with the main event occurring for 150 minutes between 17:20 and 19:50 hours (Figure 5) contributing $61.1 \%$ of recorded daily amounts, during which the discharge measurement was taken between 17:40 and 18:30 hours when a small rainfall pause before rain restarted at around 18:35 hours. The 5 events of the $12^{\text {th }}$ April occurred between 03:20 and 20:20 hours (17 hours) with two main events, the 110 minutes (08:50-10:40 hours) and 300 minutes (12:40-17:40 hours) events contributing respectively $39.3 \%$ and $34.4 \%$ of the daily amounts or a total of $73.7 \%$ in 410 minutes (6 hours, 50 minutes). With these fractions, the highest amounts on $11^{\text {th }}$ April were 54.1 and $84.4 \mathrm{~mm}$ at Kisarawe and JNIA, respectively, and 37.3 and 36.5 $\mathrm{mm}$ on $12^{\text {th }}$ April 2014. Rainfall analysis further indicated that the December 2011 events were single continuous events lasted for 250-330 minutes (Figure 6) receiving $83 \%$ of rainfall amounts in 70 minutes $\left(20^{\text {th }}\right.$ December 2011) and $81 \%$ 
amounts in 160 minutes $\left(21^{\text {st }}\right.$ December

2011).

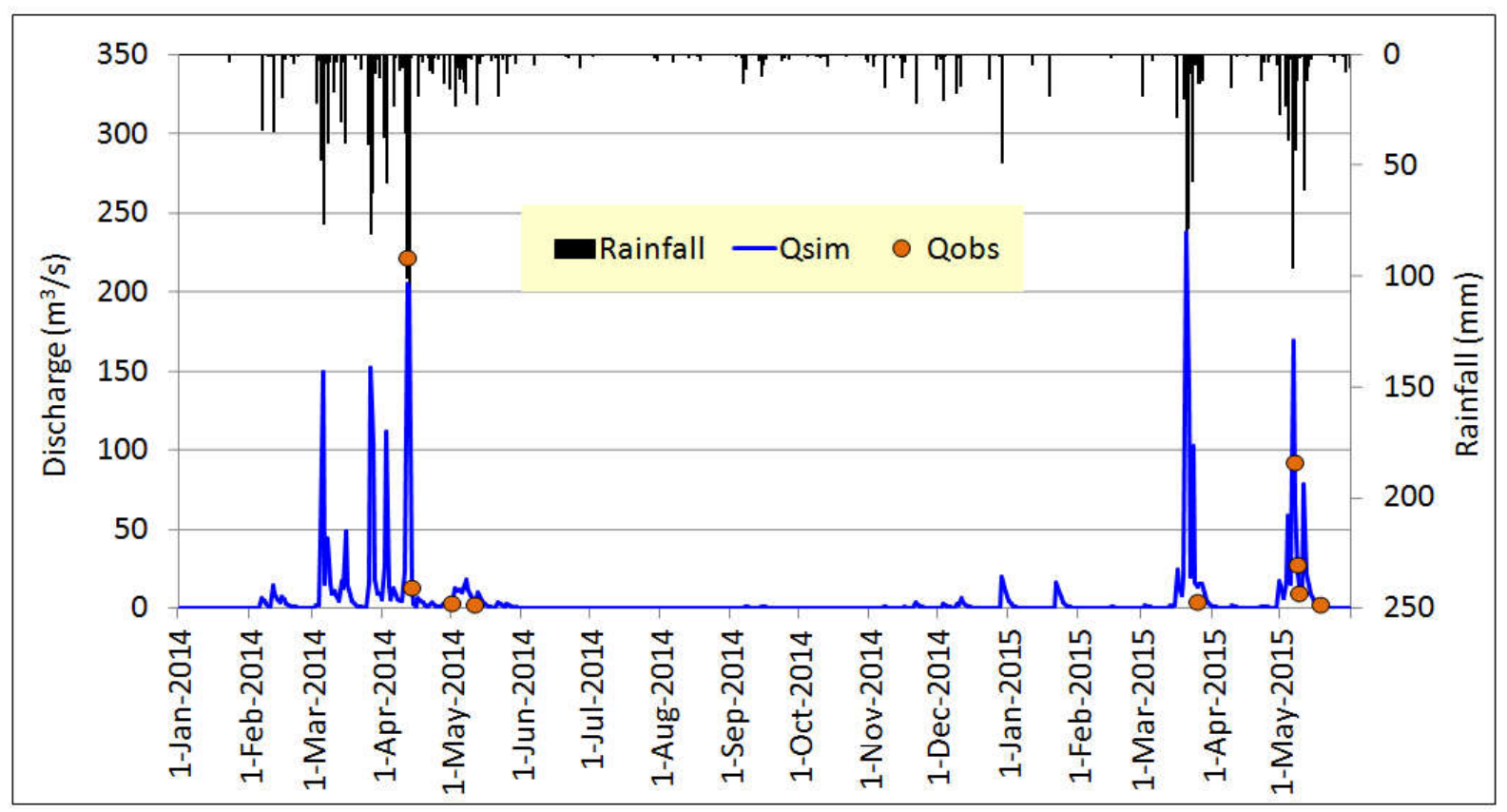

Figure 4: Simulated $\left(Q_{\text {sim }}\right)$ and measured $\left(Q_{\text {obs }}\right)$ discharges at MS1

Table 2: Measured and simulated discharges of River Msimbazi at Old StakishariSegerea Steel Bridge.

\begin{tabular}{|c|c|c|c|c|c|}
\hline \multirow[b]{2}{*}{ Date } & \multirow{2}{*}{$\begin{array}{c}\text { Observed } \\
\left(\mathbf{m}^{3} / \mathbf{s}\right)\end{array}$} & \multicolumn{2}{|c|}{ From daily climates } & \multicolumn{2}{|c|}{ From10 minutes climate } \\
\hline & & Value $\left(\mathrm{m}^{3} / \mathrm{s}\right)$ & Deviation & Value $\left(\mathrm{m}^{3} / \mathrm{s}\right)$ & Deviation \\
\hline 11-Apr-2014 & 222.01 & 205.01 & $-8 \%$ & 222.27 & $0.1 \%$ \\
\hline 13-Apr-2014 & 12.56 & 13.55 & $8 \%$ & 12.69 & $1.0 \%$ \\
\hline 1-May-2014 & 3.13 & 2.91 & $-7 \%$ & 3.21 & $2.5 \%$ \\
\hline 11-May-2014 & 1.87 & 2.30 & $23 \%$ & 1.93 & $3.0 \%$ \\
\hline 25-Mar-2015 & 4.14 & 13.33 & $222 \%$ & 4.20 & $1.5 \%$ \\
\hline 7-May-2015 & 92.38 & 65.57 & $-29 \%$ & \multirow{4}{*}{\multicolumn{2}{|c|}{ No climate data available }} \\
\hline 8-May-2015 & 27.61 & 21.37 & $-23 \%$ & & \\
\hline 9-May-2015 & 9.15 & 12.27 & $34 \%$ & & \\
\hline 18-May-2015 & 1.89 & 0.70 & $-63 \%$ & & \\
\hline
\end{tabular}

\section{Flow Recession}

Kirpich formula yields a time of concentration $\left(\mathrm{t}_{\mathrm{c}}\right)$ of 7.09 hours, which is less than 9.79 hours of a slightly larger Msimbazi catchment upstream of its River Luhanga confluence obtained by Anchors Environmental Consultants (2016). Although Anchors Environmental Consultants (2016) estimated $t_{c}$ using the Giandotti formula, the difference in $t_{c}$ of 2.69 hours was slightly longer than expected. The two sites are only $7.333 \mathrm{~km}$ apart and using this information and elevation difference $(232 \mathrm{~m}-12.8 \mathrm{~m})$ in Kirpich gives a $t_{c}$ of 8.5 hours shortening the difference to 1.4 hours, which could approximate the actual duration of a flood wave to travel from Segerea site to Jangwani site. However, the computed total $t_{c}$ from aggregation of segments $t_{c}$ using segment slopes and river lengths yielded a total $t_{c}$ of 12.6 hours, much longer than even for a large Msimbazi 
catchment upstream of River Luhanga confluence.

Simulated 10-minute discharge series (Figure 5) captured well rapid flow recession of River Msimbazi between rainfall events. The isolated rainfall events on $11^{\text {th }}$ April 2014 resulted into two main peaks with the first peak receding within 6 hours and 10 minutes and the second within 7 hours and 10 minutes, which are comparable with estimated time of concentration (7.09 hours) at the outlet location (MS1) of the modelled catchment. This feature could not be reproduced by daily series.

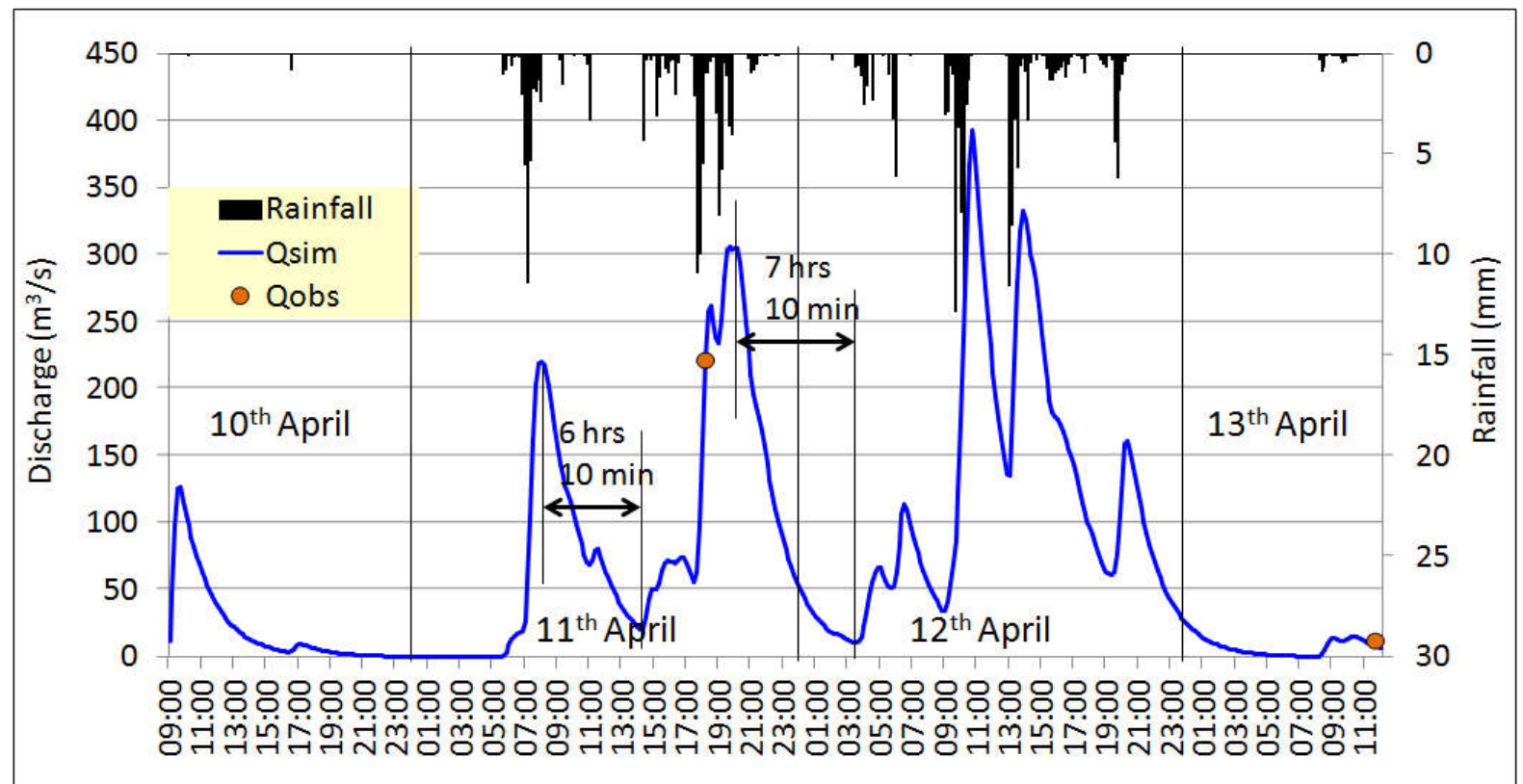

Figure 5: Simulated $\left(Q_{\text {sim }}\right)$ and spot measured $\left(Q_{\text {obs }}\right)$ discharges at MS1 between $10^{\text {th }}$ and $13^{\text {th }}$ April 2014.

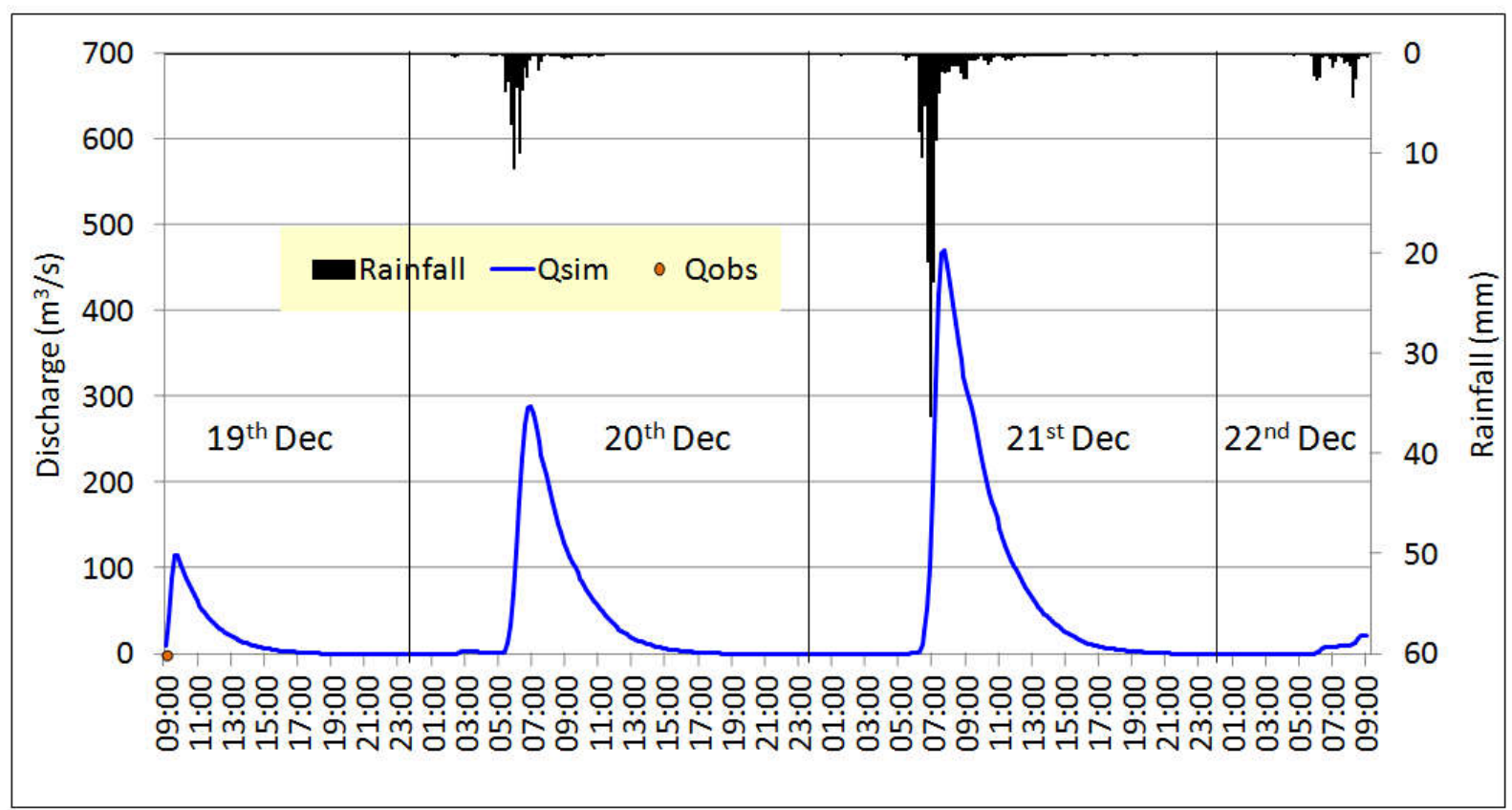

Figure 6: Simulated discharges at MS1 between $10^{\text {th }}$ and $13^{\text {th }}$ April 2014. 


\section{CONCLUSIONS}

This study was able to quantify inability of a hydrological model to simulate flood hydrographs (magnitudes and recession behaviour) of fast draining urban Msimbazi catchment using daily climate inputs. Simulation results indicated significant underestimation of flood peaks by daily climate inputs compared to 10 minutes and hourly inputs while elongating the base time of flood hydrographs. Simulated daily flows gave a December 2011 flood peak of $252.3 \mathrm{~m}^{3} / \mathrm{s}$ and a April peak of $205 \mathrm{~m}^{3} / \mathrm{s}$ whereas 10 minutes simulated flows indicated peaks of 393.5 and $471.6 \mathrm{~m}^{3} / \mathrm{s}$ for the December 2011 and April 2014 floods respectively. The daily peaks were about $52-53 \%$ of 10 minutes simulated peaks. Whilst the Kirpich method estimated a time of concentration of 7 hours, the 10-minutes simulated hydrographs captured the quick flood flow behaviour with recession durations closely matching this estimated time of concentration.

Despite usefulness of 10-minute climate data in simulating magnitude and recession behaviour of flood hydrographs in a small urban Msimbazi catchment, data for only a part of the study period were available at one station (UDSM) and missing at the other two stations (JNIA met and Kisarawe Agriculture), which contribute about 74\% of catchment area in the Msimbazi catchment. This unavailability of sub-daily climate data hindered the study of the 2015, 2016, 2017 and 2018 floods. It is therefore recommended to install automatic weather station at Kisarawe Agriculture, rehabilitate the UDSM automet station and record sub-daily (preferably hourly and less) weather data at JNIA and the former two for flood assessments in small and medium sized catchments in Dar es Salaam.

\section{ACKNOWLEDGMENTS}

The Foundation for Water Research (Tanzania) is acknowledged for providing spot discharge data and shape files for digitised rivers, roads and catchment boundaries. The Department of Water Resources Engineering of the University of Dar es Salaam is also acknowledged for availing daily and sub-daily climate data for the study. This study forms part of FRIEND SA initiative of UNESCO Water on improving data, information and knowledge availability and sharing among and between researchers, practitioners and decision-makers in water and related sectors in SADC region.

\section{REFERENCES}

Anchor Environmental Consultants (2016). Promoting green urban development in Africa: Enhancing the relationship between urbanization, environmental assets and ecosystem services - return on investment in green urban development: amelioration of flood risk in the Msimbazi river catchment, Dar es Salaam, Tanzania, International Bank for Reconstruction and Development / The World Bank, Consultancy Report, 162p.

Bárdossy A. (2007). Calibration of hydrological model parameters for ungauged catchments, Hydrol. Earth Syst. Sci., 11: 703-710. https://doi.org/10.5194/hess-11-703-2007

Bastola S., Ishidaira H. and Takeuchi K. (2008). Regionalisation of hydrological model parameters under parameter uncertainty: A case study involving TOPMODEL and basins across the globe, J. Hydrol., 357(3-4): 188 - 206. DOI: $10.1016 /$ j.jhydrol.2008.05.007

Blöschl G., Sivapalan M., Wagener T., Viglione A. and Savenije H. (2013). Runoff prediction in ungauged basins: synthesis across processes, places and scales. Cambridge University Press, New York. 
Botero B.A. and Francés F. (2010). Estimation of high return period flood quantiles using additional non-systematic information with upper bounded statistical models, Hydrol. Earth Syst. Sci., 14: 2617-2628. https://doi.org/10.5194/hess-14-26172010

Deckers D. (2006). Predicting discharge at ungauged catchments: Parameter estimation through the method of regionalization, Master Thesis, University of Twente, Enschede, 149p.

EM-DAT (2008). EM-DAT: Emergency events database, Louvain/Leuven, Centre for Research on the Epidemiology of Disaster, Université Catholique de Louvain.

Fionda A.P.A. (2011). Rainfall-runoff model application in ungauged catchments in Scotland, MSc Thesis, Uppsala University, Sweden, 79p.

Gandry M., Gailliez S., Sohier C., Verstraete A. and Dégre A. (2013). A method for low-flow estimation at ungauged sites: A case study in Wallonia (Belgium), Hydrol. Earth Syst. Sci., 17: 1319-1330. https://doi.org/10.5194/hess-17-13192013

Hargreaves G.H. and Samani Z.A. (1985). Reference Crop Evapotranspiration from Temperature, Appl. Engrg. in Agric., 1(2): 96-99. DOI: $10.13031 / 2013.26773$

Kirpich, Z.P. (1940). Time of concentration in small agricultural watersheds, Civil Eng., 10(6): 362.

Loukas A. and Vasiliades L. (2014). Streamflow simulation methods for ungauged and poorly gauged watersheds, Nat. Hazards Earth Syst. Sci., 14: 16411661. https://doi.org/10.5194/nhess-141641-2014

Mazvimavi D. (2003). Estimation of flow characteristics of ungauged catchments: Case study in Zimbabwe, Unpublished $\mathrm{PhD}$ Thesis, Wageningen University, Enschede, 188p.

Msangi R. (2017). Assesment of overflow of water on the bridge at Kimara Baruti Kilungule $A$ in Ubungo District,
Unpublished Final Year Project, University of Dar es Salaam, 44p.

Mujwahuzi E. (2011). Nyumba za bomoka, barabara kuu zafungwa, Mwananchi Newspaper, $22^{\text {nd }}$ December 2011.

Manyangu E. (2011). TMA: Hii ni mvua ya kihistoria Dar, Mwananchi Newspaper, $22^{\text {nd }}$ December 2011

Nag A. and Biswal B. (2019). Can a Calibration-Free Dynamic RainfallRunoff Model Predict FDCs in DataScarce Regions? Comparing the IDW Model with the Dynamic Budyko Model in South India, Hydrology 2019, 6, x; doi: 10.3390/hydrology6020032

Perera B.U.J. (2009). Ungauged catchment hydrology: The case of Lake Tana Basin, MSc Thesis, ITC Enschede, Netherlands, $111 p$.

Post D.A. (2004). A new method for estimating flow duration curves: An application to the Burdekin River Catchment, North Queensland, Australia, iEMSs, $6 \mathrm{p}$.

Swain J.B. and Patra K.C. (2017). Streamflow Estimation in Ungauged Catchments Using Regional Flow Duration Curve: Comparative Study, J. Hydrol. $\quad$ Engg., 22(7): https://doi.org/10.1061/(ASCE)HE.19435584.0001509

Urban Drainage and Flood Control District (UDFCD) (2018). Urban Storm Drainage Criteria Manual Volume 1: Management, Hydrology, and Hydraulics, Denver, Colorado, USA.

URT (2017). Environmental water requirements assessment guidelines, Draft, $123 p$.

Valimba P. (2016). Water Balance of Lake Rukwa, Research Report Prepared for the Ministry of Water, $157 \mathrm{p}$.

Valimba P. (2019). Development of Improved Characteristic Equations for Lake Rukwa in Tanzania. Tanzania Journal of Engineering and Technology, 38(1): 83-96. 